\title{
Kewirausahaan Bagi Ibu-Ibu Rumah Tangga Kelurahan Sungai Sibam Kecamatan Payung Sekaki Kota Pekanbaru
}

\author{
HARDI $^{1}$; NURHAYANI LUBIS ${ }^{2}$; EFRITA SOVIYANTI ${ }^{3}$ \\ Universitas Lancang Kuning \\ Jln. Yos Sudarso KM 08 Rumbai Telp. (0761) 52581 \\ E-mail : hardi@unilak.ac.id
}

\begin{abstract}
Kelurahan Sungai Sibam Kecamatan Payung sekaki is a newly divided urban village in early 2017, a population of 6,000 heads of households and a population of more than 10 thousand people. With regard to the number of people who can be an opportunity for activities that can generate additional unag for housewives. Small business development undertaken by housewives at the time after the household activity can help the family economy, Going on a small business, opening a business is not always fun. This month should be lived by many people without a choice. To enter the world of work is highly unlikely, there is no form of education only primary school graduates, junior high school, some middle schools, and sometimes no junior high school or even no elementary school finish. They come from various regions, pitting the fate of skills possessed very limited. If there is no strong will and the need to keep learning and tireless efforts to find the order, which keeps them there, is their will to live and thrive, and optimism. The benefits of entrepreneurship for those who are bigger than them, make more money, and more beneficial to others or other companies. In the economic mind as difficult as any, the entrepreneur must remain optimistic in his business. Because the courage of entrepreneurs in his business is optimistic. By staying optimistic then we will continue to be motivated and brilliant in exploiting business opportunities
\end{abstract}

Keywords: Increased Knowledge, Motivation, Entrepreneurship

Kelurahan Sungai Sibam Kecamatan Payung sekaki adalah kelurahan baru dimekarkan pada awal tahun 2017 kondisi kependudukan di daerah tersebut berkisar antara 6 ribu Kepala Keluarga dan jumalah penduduknya lebih dari 10 ribu orang. Berkenaan dengan banyaknya jumlah penduduk tentunya menjadi peluang untuk melakukan suatu kegiatan yang bisa menghasilkan unag tambahan bagi ibu-ibu rumah tangga.

Pengembangan usaha kecil yang dilakukan oleh ibu-ibu rumah tangga pada saat waktu sengang setelah mengurus rumah tangga tentunya bisa membantu perekonomian keluarga, Menjalani usaha kecil, dengan membuka sendiri usaha sendiri tak selamanya menyenangkan. Namun ini harus dijalani oleh banyak orang karena ketiadaan pilihan. Untuk memasuki dunia kerja kadang usia sudah sangat tidak memungkinkan, apalagi pendidikan formalnya hanya lulus SD, SMP, sebagian ada lulusan SMA, dan kadang justru ada yang tidak tamat SMP atau bahkan tidak tamat SD. Mereka berasal dari berbagai daerah, mengadu peruntungan ketrampilan yang dimilikipun sangat terbatas. Jika tidak ada kemauan yang kuat dan keinginan untuk terus belajar serta usaha yang tak kenal lelah untuk mencari order pekerjaan, yang membuat mereka tetap eksis, adalah kemauannya untuk terus hidup dan berkembang, serta optimisme.

Alasan utama orang membuka usaha adalah faktor ekonomi. Jika ada yang berbisnis dimulai dari hobi, jumlahnya jauh lebih sedikit daripada faktor ekonomi ini. Karena terdesak kebutuhan ekonomi, sebagian orang memilih untuk menjadi pekerja, dan sebagian lagi memilih untuk berbisnis. Resiko menjadi pekerja memang mudah, bekerja sesuai dengan tugas yang diberikan kepadanya, lalu setiap bulan 
mendapat gaji. Peluang menjalankan usaha mandiri untuk saat ini cukup banyak, salah satunya usaha kecil.

Pengembangan usaha kecil untuk dinegara berkembang, seperti di Indonesia sangatlah potensial dan sesuai dengan kondisi alam dan penduduknya. Usaha kecil mampu menyediakan lapangan pekerjaan, khususnya bagi ibu-ibu rmah tangga di kelurahan sungai sibam Kecamatan payung sekaki kota Pekanbaru. Banyak kontribusi yang dapat diberikan usaha kecil terutama bagi sektor sosial, ekonomi, namun kontribusi ini belum terealisasi secara optimal.

Berwirausaha ini memiliki banyak keuntungan yang dapat memotivasi seseorang untuk melakukan wirausaha, yakni dengan berwirausaha seseorang dapat mengatur dan merencanakan usahanya sendiri sesuai dengan tujuan yang ingin dicapai, jika memilih berwirausaha maka kita dapat menjadi pimpinan atau bos bagi usaha sendiri. Peran dari seorang wirausaha secara umum memiliki 2 peran, yaitu: sebagai penemu dan sebagai perencana. Sebagai penemu, wirausaha menemukan dan menciptakan produk baru, teknologi dan cara baru, ide-ide baru dan organisasi usaha baru. Sedangkan sebagai perencana, wirausaha berperan merancang usaha baru, merencanakan strategi perusahaan baru, merencanakan ide-ide dan peluang dalam perusahaan.

Motivasi merupakan faktor yang sangat berpengaruh pada diri seseorang untuk menentukan apa yang menjadi keinginan dan usahanya untuk mewujudkan keinginannya tersebut. Menurut Uno (2008:1), "Motivasi adalah dorongan dasar yang menggerakkan seseorang bertingkah laku. Dorongan ini berada pada diri seseorang yang menggerakkan untuk melakukan sesuatu yang sesuai dengan dorongan dalam dirinya". Jadi, semakin besar motivasi yang dimiliki seseorang, maka akan semakin besar pula usaha untuk mewujudkan tujuannya.

Salah satu upaya untuk mengatasi adanya angka pengangguran yang besar dapat diperkecil dengan cara berwirausaha. Wirausaha merupakan alternatif pilihan yang tepat untuk mengatasi pengangguran. Berwirausaha berarti membuka lapangan kerja baru dan berperan serta mengatasi masalah pengangguran.

Usaha kecil adalah kegiatan ekonomi rakyat yang berskala kecil dan memenuhi kriteria kekayaan atau hasil penjualan tahunan serta kepemilikkannya sebagaimana diatur dalam undang undang ini:

1. Memiliki kekayaan paling banyak Rp. 200.000.000 (dua ratus juta Rupiah) Tidak termasuk tanah dan bangunan tempat usaha.

2. Memilki hasil penjualan tahunan paling banyak Rp. 1000.000.000 (satu milyar rupiah)

3. Milik warga negara Indonesia

4. Berdiri sendiri, bukan merupakan anak perusahaan atau cabang perusahaan yang dimiliki. Dikuasasi atau berafiliasi baik langsung maupun tidak langsung dengan usaha menengah atau usaha besar.

5. Berbentuk usaha orang perseorangan, badan usaha yang tidak berbadan hukum atau badan usaha yang berbadan hukum, termasuk koperasi (UU No. 9; 1995;5)

Konsep usaha kecil itu sendiri sesungguhnya, dari 48,9 juta usaha kecil diIndonesia, hanya 1 juta unit lebih yang benar benar dapat disebut sebagai pengusaha kecil. Koperasipun hanya 80 ribu lebih , lebih dari 47,50 juta pengusaha sesungguhnya dikategorikan sebagai usaha mikro. Dengan demikian bila kita bicara tentang usaha mikro kecil menengah perlu diingat bahwa sebetulnya kebayakan usaha yang kita bahas itu bersifat sangat kecil. Sampai saat ini masih banyak perbedaan mengenai kriteria pengusaha kecil baik yang ada dikalangan perbankan, lembaga terkait, Biro Pusat Statistik (BPS), maupun kamar dagang dan industri Indonesia (KADIN), perbedaan kriteria tersebut 
adalah Bank Indonesia suatu perusahaan perorangan yang mempunyai total asset maksimal Rp. 600 juta tidak termasuk tanah dan rumah yang ditempati. Untuk departemen perindustrian kriteria usaha kecil sama dengan Bank Indonesia. Biro Pusat Statistik (BPS), usaha rumah tangga yang mempunyai $1-5$ tenaga kerja, usaha kecil mempunyai 6 -19 tenaga kerja, usaha menengah mempunyai 20 -99 tenaga kerja. Kamar Dagang Industri Indonesia (KADIN). Industri yang mempunyai total asset maksimal Rp. 600 juta termasuk rumah dan tanah yang ditempati dengan jumlah tenaga kerja dibawah 250 orang. Departemen keuangan : suatu badan usaha atau perorangan yang mempunyai asset setinggi tingginya 300 juta atau mempunyai omset penjualannya maksimal Rp. 300 juta pertahun. (Abdullah Abidin; 2013;2)

Tidak kenal sama sekali dengan dunia wirausaha bukanlah alasan bagi seseorang untuk tidak mencoba sebuah peluang usaha kecil, meskipun tidak tahu sama sekali tentang bagaimana cara memulai sebuah bisnis, namun kesempatan untuk berwirausaha selalu terbuka lebar, dan mengambil sebuah usaha kecil bisa menjadi solusi tepat untuk membiasakan diri dengan menghasilkan uang secara mandiritanpa harus selalu bergantung dengan lapangan pekerjaan yang didirikan orang lain. Sebuah usaha kecil kecilan bisa dipilih ssebagai langkah membiasakan diri dengan dunia wirausaha mandiri. Berwirausaha mandiri bisa menjadi seseorang lebih tangguh dalam menghadapi tantangan kehidupan. Perlu diketahui juga bahwa berwirausaha itu sangat penting karena nilai atau uang yang dihasilkan dari usaha mandiri yang dijalankan tentunya tak terbatas jumlahnya selagi orang tersebut mau bekerja keras.

Kewirausahaan adalah disiplin ilmu yang mempelajari tentang nilai, kemampuan, dari prilaku seseorang dalam mengahadapi tantangan hidup untuk memperoleh peluang dengan berbagai resiko yang mungkin dihadapinya. (Sudayono; Asep Saefullah; 2011;9).

Diklat Review: Jurnal Manajemen Pendidikan dan Pelatihan
Ada beberapa definisi wirausaha menurut :

1. Pandangan Ahli Ekonomi : Wirausaha adalah orang yang mengkombinasikan faktor faktor produksi seperti sumber daya alam, tenaga kerja, material, dan peralatan lain untuk meningkatkan nilai sehingga menjadi lebih tinggi dari sebelumnya.

2. Pandangan pelaku bisnis: pelopor dalam bisnis , Inovator, penanggung resiko yang mempunyai visi, kedepan, dan memiliki keunggulan dalam prestasi dibidang usaha.

3. Pandangan Psikolog : Wirausaha adalah orang yang memiliki dorongan kekuatan dari dalam diri untuk memperoleh suatu tujuan serta suka bereksperimenuntuk menampilkan kebebasan dirinya diluar kekuasaaan orang lain.

Beberapa manfaat kewirausahaan adalah sebagai berikut :

1. Memberi peluang dan kebebasan untuk mengendalikan nasib sendiri.

2. Memberi peluang melakukan perubahan

3. Memberi peluang untuk mencapai potensi diri sepenuhnya

4. Memiliki peluang untuk meraih keuntungan seoptimal mungkin.

5. Memiliki peluang untuk berperan aktif dalam masyarakat dan mendapat pengakuan atas usahanya.

6. Memiliki peluang untuk melakukan sesuatu yang disukai menumbuhkan rasa senang dalam mengerjakannya.

Semangat kewirausahaan yang perlu dibudayakan antara lain :

1. Kemauan kuat untuk berkarya (utamanya dibidang ekonomi) dengan semangat mandiri

2. Mampu membuat keputusan yang tepat dan berani mengambil resiko

3. Kreatif dan inovatif 
4. Tekun, teliti, dan produktif

5. Berkarya dengan semangat kebersamaan dan etika bisnis yang sehat

Berdasarkan kelima semangat kewirausahaan tersebut maka jelas bahwa yang dibutuhkan oleh seorang pengusaha atau wirausaha adalah berkarya dengan semangat mandiri yang disertai dengan semangat kebersamaan dan kekeluargaan . Hal ini menunjukkan bahwa wirausaha hanya memikirkan bisnisnya sendiri, melainkan juga dituntut untuk memperhatikan bisnis orang lain. Dengan kata lain, tidak boleh saling menjatuhkan, terutama pada bisnis sejenis. Persaingan harus dilakukan secara sehat agar mendorong munculnya wirausaha wirausaha baru yang tangguh, kreatif, inovatif, produktif namun tetap menjaga karakter bangsa Indonesia yang ramah, bergotong royong persaudaraan sejati, dan tidak melanggar etika bisnis.

Prinsip prinsip kewirausahaan menurut Khafidlul Ulum :

1. Passion (semangat)

2. Independent (Mandiri)

3. Marketing sensitivity (peka terhadap pasar)

4. Creative and Innovative (kreatif dan inovatif)

5. Calculated risk taker (mengambil resiko dengan penuh perhitungan )

6. Persistent (pantang menyerah)

7. High ethical standard (berstandar etika tinggi)

Jika digabungkan prinsip prinsip kewirausahaan dari kedua pendapat tersebut diatas adalah sebagai berikut;

1. Jangan takut gagal

2. Penuh semangat

3. Kreatif dan inovatif

4. Bertindak dengan penuh perhitungan dalam mengambil resiko

5. Sabar, ulet, tekun

6. Harus optimis

7. Ambisius

8. Pantang menyerah/jangan putus asa

9. Peka terhadap pasar/dapat membaca peluang pasar
10. Berbisnis dengan standar etika

11. Mandiri

12. Jujur

13. Peduli lingkungan

Wirausahawan

adalah seseorang yang mengorganisasikan, mengoperasikan dan memperhitungkan resiko untuk sebuah usaha yang mendatangkan laba. Seorang pelaku usaha telah melakukan pengorganisasian terhadap sumber daya yang dimilikinya dalam ruang dan dimensi yang terbatas dan berusaha mengoperasikan sebagai kegiatan usaha guna mencapai laba. Dalam mengorganisasikan dan mengoperasikan usaha tersebut, pasti berhadapan dengan sejumlah resiko, utamanya resiko kegagalan.(Mulyadi Nitisusastro;2009;27)

Agar efektif, seorang pemimpin perusahaan kecil harus melakukan tugas tugas yang sangat penting, termasuk yang berikut ini:

a. Menerima karyawan yang tepat dan selalu berusaha memeprbaiki kemampuan mereka.

b. Membangun budaya untuk mempertahankan karyawan

c. Merencanakan "penyerahan estafet" ke generasi kepemimpinan yang berikutnya. (Thomas w. Zimmerer, alih bahasa Deny Arnos Kwary; 2009; 412)

Wirausahawan adalah Seseorang yang menciptakan bisnis baru dengan mengambil risiko dan ketidakpastian demi mencapai keuntungan dan pertumbuhan dengan cara mengidentifikasi berbagai peluang penting dan menggabungkan sumber daya yang diperlukan untuk mengoptimalisasikan sumber daya sumber daya itu. (Thomas W. Zimmerer, alih bahasa Deny Arnoa Kwary;2009;6). Berikut ini ciri ciri untuk mencapai sukses mengenai profil wirausahawan :

1. Hasrat akan tanggung jawab

2. Lebih menyukai resiko menengah

3. Menyakini kemampuannya untuk sukses 
4. Hasrat untuk mendapatkan umpan balik yang sifatnya segera

5. Tingkat energi yang tinggi

6. Orientasi masa depan

7. Ketrampilan mengorangisasi

8. Menilai prestasi lebih tinggi daripada uang

Manfaat kewirausahaan ditunjukkan bahwa pemilik bisnis kecil menyakini bahwa mereka bekerja lebih keras, menghasilkan lebih banyak uang, dan merasa lebih bahagia daripada bekerja untuk orang lain atau perusahaan lain. Dalam situasi ekonomi sesulit apapun, wirausaha harus tetap optimis dalam menggeluti bisnisnya. Sebab keberanian wirausaha dalam menggeluti bisnisnya terletak pada optimisme. Dengan tetap optimis maka kita akan terus termotivasi dan cemerlang dalam memanfaatkan peluang bisnis.

Melihat kondisi di Kelurahan Sungai Sinam Kecamatan Payung Sekaki Kota Pekanbaru khususnya di RT 03 RW 01 dan Perum Damai Indah Mandiri, ibuibu rumah tangga masih banyak mempunyai waktu luang yang bisa dimanfaatkan utuk kegiatan produktif, Ibuibu rumah tangga belum begitu merespon tentang peluang waktu yang sengang tersebut untuk melakukan kegiatan mencari tambahan penghasilan dari kewirausaan.

Kurangnya respon ibu-ibu rumah tangga terebut belum adanya yang memotivasi untuk bisa berkreatif untuk melakukan kewirausahaan disaat waktu luang setelah selesai melaksanakan keguatan rumah tangga mereka. Adapun permasalahan yang dihadapi oleh mitra dalam hal ini adalah belum maksimalnya Pemahaman dari kewirausahaan dan Motivasi ibu-ibu rumah tangga tersebut.

\section{METODE}

Dalam kegiatan pengabdian masyarakat ini ada beberapa tahap metode pelaksanaan yang akan dihadapi oleh tim pengabdian dan mitra antara lain: Waktu dan Tempat: waktu dari kegitan pengabdian kepada masyarakat ini dilaksanakan satu kali tatap muka pada bulan Maret 2018 dan tempat pelaksanaan akan dilakasanakan di Kelurahan Sungai Sibam. Program kegiatan: Persiapan dari tim pengabdian, Penyampain materi yang akan disampaikan pada saat pelaksanaan, Pre tes dan Pos tes: Kegiatan ini bertujuan untuk mengukur pemahaman dan motivasi Ibu-ibu rumah tangga tentang mengahasilkan unag tambahan dari berwirausaha. Pre-test dan Post-test berupa pengujian ibu-ibu rumah tangga dengan memberi kuisioner. Instrumen Pelaksanaan: Instrumen yang dibutuhkan adalah Materi pengabdian, laptop, Infocus dan melibatkan motivator pelaku usaha kecil dan menengah kota Pekanbaru.

\section{HASIL}

Pelaksanaan kegiatan pengabdian kepada Mahasiswa Universitas Lancang Kuning. Kegiatan pengabdian ini dilaksanakan pada bulan Maret s/d Juni 2018. Para peserta yang hadir pada waktu pelaksanaan kegiatan ini adalah Ibu-ibu di Kelurahan Sungai Sibam Kecamatan Payung Sekaki Kota Pekanbaru khususnya di RT 03 RW 01 dan Perum Damai Indah Mandiri.

Adapun peserta ibu-ibu rumah tangga yang sebagian waktu luangnya cukup banyak dalam kegiatan usaha sampingan, dari peserta yang kita harapkan sekitar 20 orang dari mitra kelompok pengabdian. Dari harapan tersebut ternyata pesertanya yang datang sebanyak 15 orang yang bisa mengikuti kegiatan Pengabdian Kepada Masyarakat tersebut.

Dari hasil ceramah, diskusi, tanya jawab, kami dapat menyimpulkan bahwa peserta sebagian besar belum memanfatkan waktu lunag untuk hal kewirausahaan yang pada intinya agar mendapat uang tambahan, dan juga belum termotivasi dalam kegiatan kewirausahaan memfaatkan waktu luang dikarenakan kurangnya pemahaman akan pentingnya dari Usaha Sampingan. hal ini dapat dilihat dari hasil kuisioner sebelum dan sesudah mendapat pembekalan dan materi tentang pemahaman tentang 
Kewirausahaan dalam memanfaatkan keahlian dan waktu lunag dalam pembuatan jajanan yang bisa dijual.

Pada akhir sesi dari pengabdian masyarakat ini, para peserta pengabdian mulai memahami apa itu motivasi berwirausaha dan menmanfaatkan waktu luang untuk mendapatkan penghasilan tambahan. Yang perlu kami tekankan disini, bahwa dengan kemampuan skill dan keinginan yang kuat dari masyarakat khusunya RT 03 RW 01 dan Perum Damai Indah Mandiri., kita dapat menyakinkan bahwa meskipun susah untuk memulai usaha sampingan dalam memanfaatkan waktu luang dengan adanya doorongan dari tim Pengabdian peserta pengabdian mulai mau untuk memanfaatkan waktu luangnya untuk berwirausaha

\section{PEMBAHASAN}

Peningkatan

pengetahuan, pemahaman dan motivasi bagi Kelompok ibu-ibu RT 003 RW 001 dan ibu-ibu Perumahan Damai Indah Mandiri adalah merupakan bagian yang sangat penting dan harus diketahui oleh para peserta untuk memaksimalkan waktu luang dan termotivasi untuk melakukan wirausaha dalam memanfaatkan waktu luang. Untuk membuat peserta pengabdian bisa mengerti dan bisa termotivasi dalam berwirausaha, tidak hanya diperlukan modal, tetapi juga tekad, ketrampilan, pengetahuan, ketekunan, berani memulai. Hal ini sejalan dengan apa yang dikatakan Novita, N. (2016) bahwa adanya kreatifitas kelompok masyarakat khususnya ibu-ibu rumah tangga dalam menghadapi kondisi ekonomi dengan menambah pengetahuan melalui bergabung dalam kelompok masyarakat. Juga dalam penelitian lainnya disebutkan bahwa melalui kelompok di masyarakat akan meningkatkan kewirausahaan ibu rumah tangga.

Ibu-ibu kami motivasi untuk membuat jajanan yang disukai oleh masyarakat tempatan kami dari tim Pengabdian berusaha memotivasi dengan cara berdiskusi tanya jawab mengenai apa hobinya agar bisa kami beri alternatif usaha yang akan dijalani di sekitar perumahan. Keterbatasan pengetahuan dan pemahaman peserta dalam kewirausahaan dan motivasi dalam memanfaatkan waktu luang memang tidak mudah untuk dilaksanakan oleh ibuibu mitra pengabdian. Peningkatan pemahaman dalam berwirausaha dan motivasi untuk memulai usaha.

Dalam kegiatan pengabdian masyarakat ini dengan cara menyebarkan quisioner sebelum dan sesudah pelaksanaan pelaksanaan pengabdian. Adapun untuk mengetahui pengetahuan dan pemahaman tentang Kewirausahaan dan Motivasi dalam pemanfaatan waktu luang, dapat dilihat dari pertanyaan yang telah dijawab bahwa jawaban peserta sebelum dilakukan pembekalan dan yang mejawab Ya berdasarkan tabel diatas sebanyak 3 peserta dan yang menjawab belum sebanyak 12 peserta. Sedangkan setelah diadakan penjelasan tentang keiwirausahaan dan Motivasi memanfaatkan waktu luang untuk berwirausaha 15 orang peserta mengerti bagaimana cara memanfaatkan waktu luang untuk mendapatakan uang tambahan sambil memanfaat waktu luang membuat jajanan yang disukai oleh Anak-anak setempat hal tersebut yang akan meningkatkan pemahaman akan pentingya wirausaha.

Selanjutnya untuk mengetahui para peserta sudah pernah atau belum mendapatkan pengetahuan tentang bisa membuat jajanan bakso ikan patin untuk keluarga dapat dilihat jawaban responden sebelum mendapatkan pembekalan atau penyuluhan tentang usaha mandiri, atau berwirausaha dalam memanfaatkan waktu luang pada kegiatan Kewirausahaan Bagi Ibu-ibu Rumah Tangga Kelurahan Sungai Sibam Kecamatan Payung Sekaki Kota Pekanbaru bagi Ibu Rumah Tangga RT 003 RW 001 dan ibu-ibu Perum Damai bahwa ibu-ibu mitra pengabdian yang menjawab belum yaitu semua peserta. Dengan demikian sebagian besar peserta belum pernah mendapatkan pemahaman tentang Usaha mandiri dan berwirausaha, dan sebagian peserta mengatakan bahwa pemahaman tentang motivasi dan 
berwirausaha memerlukan kodal yang besar. Selanjutnya untuk mengetahui pemahaman tentang lebih memilih membeli makanan jajanan untuk anak atau membuatnya sendiri dapat dilihat bahwa jawaban responden sebelum diadakan pembekalan tentang motivasi dalam berusaha banyak yang menjawab tidak dan belum memahamainya, akan tetapi setelah kita berikan materi seluruh peserta hampir memahaminya. Pemahaman tentang motivasi dan berusaha mandiri kami dari tim Pengabdian berusaha mengunakan media teknologi untuk bisa menampilkan usaha-usaha yang bisa dijalani oleh mitra pengabdian dengan cara memberikan photo dan video mengunakan laptop dan infocus, dengan mengunakan media teknologi dapat dilihat antusias ibu-ibu tersebut dalam meperhatikannya dan bisa dilihat juga pada quesioner yang telah kita sebarkan tersebut semua mengerti tentang motivasi dalam berusahan dalam memnafaatkan waktu luang.

Sebelum dimulainya penyampaian materi dan pemberian pembekalan kewirausaaan dan motivasi berusaha tentang Kewirausahaan Bagi Ibu-ibu Rumah Tangga Kelurahan Sungai Sibam Kecamatan Payung Sekaki Kota Pekanbaru, kami Tim Pengabdian Masyarakat memberikan kuisioner terlebih dahulu untuk mengetahui sampai sejauh mana para peserta memahami dan mengerti tentang Kewirausahaan dan motivasi dalam memanfaatkan waktu luang untuk berwirausaha. Setelah dievaluasi ternyata kurang dari separuh peserta pengabdian tersebut belum memahami bagaimana Wirausaha mandiri dan motivasi berusaha dalam memanfaatkan waktu luang dan memanfaatkan masyarakat tempatan atas produk yang dihasikan.

Kemudian pada akhir April 2018 kami melanjutkan untuk memberikan materi dan pembekalan bagaimana Kewirausahaan Bagi Ibu-ibu Rumah Tangga Kelurahan Sungai Sibam Kecamatan Payung Sekaki Kota Pekanbaru. Dilihat dari pantauan kami, memang diskusi dan tanya jawab yang kami berikan berpengaruh terhadap penerimaan materi yang kami berikan, untuk ibu-ibu peserta kegiatan Pengabdian cepat memahami apa yang disampaikan oleh Tim Kami. Dalam melaksanakan kegiatan Kewirausahaan Bagi Ibu-ibu Rumah Tangga Kelurahan Sungai Sibam Kecamatan Payung Sekaki Kota Pekanbaru mitra pengabdian cepat memahami bagaimana berusaha mandiri dan motivasi berusaha dalam memanfaatkan waktu luang. Hal serupa disampaikan oleh Rahman, F. (2017) bahwa waktu atau kesempatan waktu luang menjadi sebuah investasi yang besar, dalam memanfaatkan waktu akan menumbuhkan jiwa wirausaha.

Pada Dasarnya para peserta antusias dalam menerima materi yang diberikan oleh Tim Pengabdian Masyarakat, kita juga maklum dengan keterbatasan kemampuan nalar yang belum terarah untuk bagaimana jajanan sehat dibuat sendiri bukan dibeli. Maka dalam memberikan Kewirausahaan Bagi Ibu-ibu Rumah Tangga Kelurahan Sungai Sibam Kecamatan Payung Sekaki Kota Pekanbaru bagi Ibu-ibu RT 003 RW 001 dan Ibu-ibu Rumah tangga Perum damai indah mandiri, materi kewirausahaan dan motivasi dalam berusaha kita harus mengulang mengulang sampe mereka dapat memahaminya dan bisa diaplikasi setelah berakhirnya pengabdian tersebut. Sebagaimana dijelaskan pada kajian sebelumnya oleh Hardi, H. (2017) bahwa usaha lembaga tinggi memberikan pengetahuan kepada masyarakat mendapatkan dukungan positif oleh masyarakat karena hal ini menunjukkan peran nyata bagi masyarakat.

\section{SIMPULAN}

Dari uraian di atas maka dapat disimpulkan bahwa pada tahap awalnya sebelum pemberian pembekalan tentang kewirausahaan dan motivasi usaha mandiri pengabdian masyarakat ini diikuti sekitar 15 peserta, Kelompok ibu-ibu Perumahan Damai Indah Mandiri dan ibu-ibu RT.003 RW 001. Kemudian pada tahap kedua, yang diikuti oleh seluruhnya yaitu 15 peserta, Para peserta sebelum diadakan pembekalan tentang kewirausahaan dan motivasi usaha 
mandiri, banyak yang belum memahami arti pentingnya mendapatkan uang sampingan dalam memanfaatkan waktu luang berusaha. Dan setelah dilakukan pembekalan tentang Kewirausahaan Bagi Ibu-ibu Rumah Tangga Kelurahan Sungai Sibam Kecamatan Payung Sekaki Kota Pekanbaru, mereka mulai memahami meskipun sulit untuk dapat menerapkannya, karena pemikiran para ibuibu dari kelompok mitra tersebut bahwa membeli lebih murah dan membuat lebih mahal.

\section{DAFTAR RUJUKAN}

Abdullah Abiding, SE, 2013, Jurnal Koperasi dan UMKM, Universitas Hasanuddin, www.bimakab.go.id

Asep Saefullah, 2011, Kewirausahaan, Penerbit andi Yogyakarta

Erick Namara, 2007, 101 peluang bisnis, penerbit Media Pressindo, Yogyakarta

H. Moko. P. Asta Moen, 2008, Entrepreneurship, penerbit Alfabeta,

Hardi, H. (2017). Peningkatan Pemahaman Pembuatan Bakso Dari Ikan Patin Dalam Jajanan Sehat Untuk Keluarga. Jurnal Diklat Review, 1(3), 129-133.

Indah Ratnaningsih, 2010, 99 bisnis, penerbit Penebar Pew, Jakarta

Kasmir, 2006, kewirausahaan, Penerbit PT. Raja Grafindo Persada Jakarta

Mulkyadi Nitisusastro, 2009, Kewirausahaan \&Manajemen Usaha Kecil, penerbit Alfabeta Bandung

Martin Perry, 2002, Mengembangkan usaha kecil, penerbit PT. Rajagrafindo Persada, Jakarta
Novita, N. (2016). Analisis Kreatifitas Kelompok Masyarakat Menghadapi Kondisi Ekonomi Rumah Tangga. Jurnal Daya Saing, 2(2), 150-159.

Riau, S. T. I. E. Motivasi Perempuan Berwirausaha Melalui Kelompok Arisan Program Pemberdayaan Masyarakat (Pkk) Di Kota Pekanbaru.

Rahman, F. (2017). Peran Modal Manusia Dan Modal Investasi Terhadap Nilai Produksi Industri Kecil Di Kota Pekanbaru. Jurnal Benefita, 2(1), 1-9.

Sugiarto, 2007, Undang undang dan peraturan tentang usaha kecil dan menengah, penerbit Visi

Media, Jakarta.

Thomas W. Zimmerer, Norman M. Scarborough, 2008, kewirausahaan dan manajemen usaha kecil, edisi 5 buku 2, penerbit Salemba Empat Bandung 